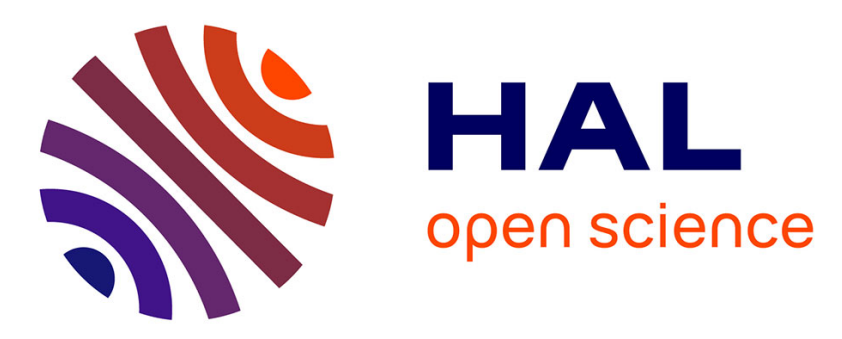

\title{
Recovery of toluene from high temperature boiling absorbents by pervaporation
}

F. Heymes, P Manno Demoustier, F. Charbit, Jean-Louis Fanlo, Philippe Moulin

\section{- To cite this version:}

F. Heymes, P Manno Demoustier, F. Charbit, Jean-Louis Fanlo, Philippe Moulin. Recovery of toluene from high temperature boiling absorbents by pervaporation. Journal of Membrane Science, 2006, 284 (1-2), pp.145 - 154. 10.1016/j.memsci.2006.07.029 . hal-01916633

\section{HAL Id: hal-01916633 \\ https://hal.science/hal-01916633}

Submitted on 25 Nov 2020

HAL is a multi-disciplinary open access archive for the deposit and dissemination of scientific research documents, whether they are published or not. The documents may come from teaching and research institutions in France or abroad, or from public or private research centers.
L'archive ouverte pluridisciplinaire HAL, est destinée au dépôt et à la diffusion de documents scientifiques de niveau recherche, publiés ou non, émanant des établissements d'enseignement et de recherche français ou étrangers, des laboratoires publics ou privés. 
archives-ouvertes

\title{
Recovery of toluene from high temperature boiling absorbents by pervaporation
}

\author{
F. Heymes, P. Demoustier, F. Charbit, J.L. Fanlo, Philippe Moulin
}

\section{To cite this version:}

F. Heymes, P. Demoustier, F. Charbit, J.L. Fanlo, Philippe Moulin. Recovery of toluene from high temperature boiling absorbents by pervaporation. Journal of Membrane Science, Elsevier, 2006, 284 (1-2), pp.145 - 154. 10.1016/j.memsci.2006.07.029 . hal-01916633

\section{HAL Id: hal-01916633 \\ https://hal.archives-ouvertes.fr/hal-01916633}

Submitted on 25 Nov 2020

HAL is a multi-disciplinary open access archive for the deposit and dissemination of scientific research documents, whether they are published or not. The documents may come from teaching and research institutions in France or abroad, or from public or private research centers.
L'archive ouverte pluridisciplinaire HAL, est destinée au dépôt et à la diffusion de documents scientifiques de niveau recherche, publiés ou non, émanant des établissements d'enseignement et de recherche français ou étrangers, des laboratoires publics ou privés. 


\title{
Recovery of toluene from high temperature boiling absorbents by pervaporation
}

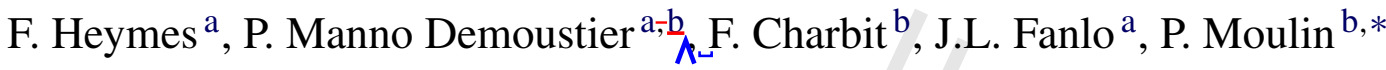

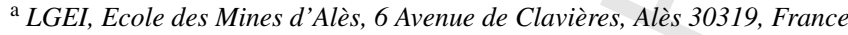 \\ ${ }^{\mathrm{b}}$ LPPE, Université Paul Cézanne, Bâtiment Laennec, Hall C, Europole de l'Arbois, BP 80, Aix en Provence 13545, France
}

Received 15 March 2006; received in revised form 13 July 2006; accepted 19 July 2006

\begin{abstract}
The treatment of gaseous effluents containing hydrophobic volatile organic compounds (VOCS) can be carried out by absorption with the use of a heavy hydrophobic solvent. These solvents must be regenerated in order to be reused in the absorption process. A possible solution to continuously regenerate the absorbent is a hybrid absorption-pervaporation process, with the pervaporation step serving to regenerate the solvent. This piece of research examines the feasibility of that regeneration step. The VOC used was toluene and three high temperature boiling absorbents were considered: di(2-ethylhexyl) adipate (DEHA), diisobutyl phthalate (DIBP) and polyethylene glycol 400 (PEG 400).

Bibliographical research and a preliminary theoretical evaluation led to the choice of PDMS for separating the toluene/absorbent mixture, whatever the absorbent. Experiments using various absorbents showed that toluene passed through the membrane. The extracted toluene flows from DEHA were considerably higher that those measured using diisobutyl phthalate or polyethylene glycol. Therefore, di(2-ethylhexyl) adipate would be the most easily regenerable absorbent.

No absorbent was found in the permeate, but a slow accumulation of DEHA was observed in the porous support. This point is of interest and could decrease the separation efficiency.

The predominant effect of the liquid boundary layer was highlighted. The resistance-in-series theory allowed the impact of the boundary layer to be quantified. The flow rates of toluene extraction from a DEHA solution were low and require improving the pervaporation regeneration performance to use this kind of separation in an industrial hybrid process.
\end{abstract}

Keywords: Pervaporation; Toluene; Adipate; Phthalate; Polyethylene glycol

\section{Introduction}

Volatile organic compounds (VOCS) are produced from human activities and may cause health problems for humans or damages to environment. To reduce these harmful emissions, legislations have been set up to control industrial discharges into the atmosphere (USA Clean Air Act amendments, EEC directives). Therefore, industries either reconsider the production process to reduce their emissions or more frequently, set up an end-of-pipe treatment unit. There are a number of existing and emerging technologies for end-of-pipe VOC control: thermal or catalytic oxidation, condensation, adsorption, membrane separation, biological treatments or absorption. Absorption can

\footnotetext{
* Corresponding author. Tel.: +334429085 05; fax: +33442908515.

E-mail address: philippe.moulin@univ-cezanne.fr (P. Moulin).
}

be carried out with water in the case of hydrophilic VOCs absorption but, in case of hydrophobic VOCs such as toluene, other kinds of absorbents are required. High temperature boiling oils revealed a high efficiency to treat hydrophobic VOCs. The remaining problem is what to do with the used absorbent: obviously one solution is to regenerate the absorbent by removing the absorbed VOCs. Among the classical chemical engineering operations of separation, distillation and stripping are commonly used in industry. These processes are efficient but quite expensive and therefore not suitable for air treatment. As a result, only few hybrid processes coupling an absorption tower with a regeneration step are employed in industry.

The process considered in this work is a hybrid absorption-pervaporation process based on a continuous regeneration of the used absorbent (Fig. 1). Several authors previously investigated the possibility to use this kind of system. Poddar et al. [1-3] studied a process coupling a hollow 


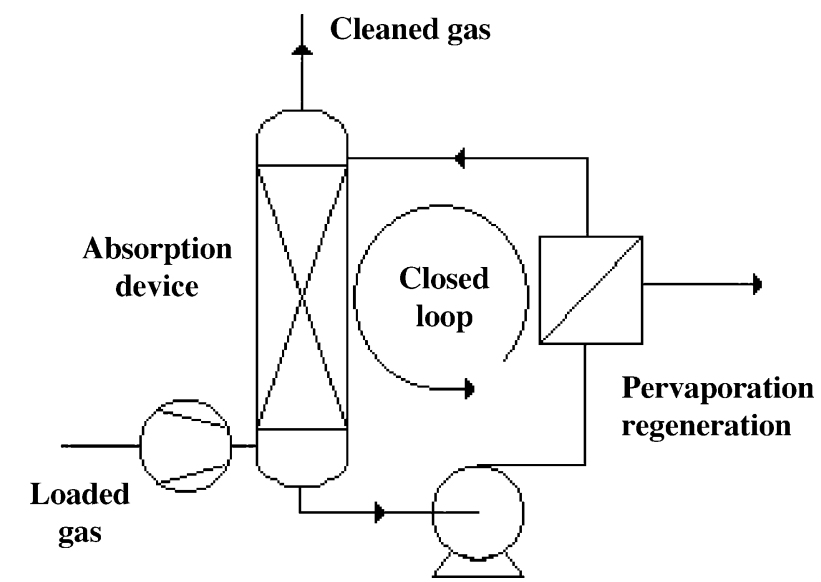

Fig. 1. Hybrid absorption-pervaporation process.

Table 1

Properties of the studied absorbents

\begin{tabular}{llllllr}
\hline Component & $\begin{array}{l}\text { Boiling } \\
\text { point }\left({ }^{\circ} \mathrm{C}\right)\end{array}$ & $\begin{array}{l}\text { Molar weight } \\
\left(\mathrm{g} \mathrm{mol}^{-1}\right)\end{array}$ & $\begin{array}{l}\text { Density } \\
\left(\mathrm{kg} \mathrm{m}^{-3}\right)\end{array}$ & $\begin{array}{l}\text { Viscosity at } \\
20^{\circ} \mathrm{C}(\mathrm{Pa} \mathrm{s})\end{array}$ & $\begin{array}{l}\text { Henry's coefficient } H \\
\left(25^{\circ} \mathrm{C}\right)\left(\mathrm{Pa} \mathrm{m}^{3} \mathrm{~kg}^{-1}\right)\end{array}$ & $\begin{array}{l}\text { Solubility parameter } \\
\left(\mathrm{cal} \mathrm{cm}^{-3}\right)^{1 / 2}\end{array}$ \\
\hline DEHA & 210 & 351 & 930 & 0.0125 & 7.74 & 8.1 \\
DIBP & 320 & 278 & 1043 & 0.0378 & 9.73 & 9.0 \\
PEG 400 & 250 & 400 & 1130 & 0.1336 & 15.27 & 10.1
\end{tabular}

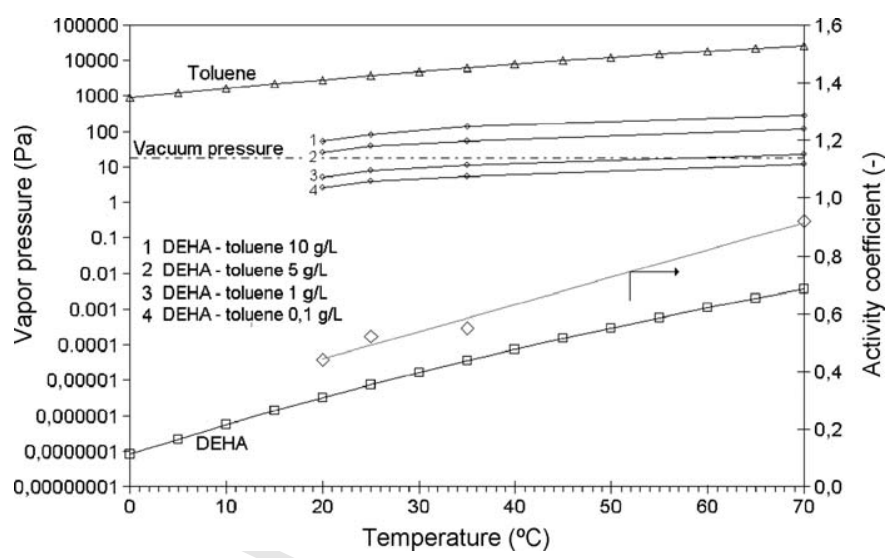

Fig. 2. Vapor equilibrium of different liquids.

\subsection{Choice of the membrane}

The chemical structures of toluene and the different absorbents are very different. A molar weight difference between toluene $\left(92 \mathrm{~g} \mathrm{~mol}^{-1}\right)$ and the different absorbents as well as a sharp boiling temperature difference between toluene $\left(105.6^{\circ} \mathrm{C}\right)$ and the different absorbents can be noticed (Table 1). Previous experiments [5,6] investigated thermodynamic vapor-liquid equilibriums and enabled to calculate the vapor pressure of pure toluene, pure DEHA and toluene above toluene-DEHA mixtures as a function of temperature. Results are given in Fig. 2. A linear relationship between the toluene vapor pressure and the toluene fraction in the liquid was observed up to $x=0.057\left(13.20 \mathrm{~g} \mathrm{~L}^{-1}\right.$ in DEHA), which is a little extended in regards with the usual validity range [7]. The Henry's law coefficients for that linear range are given in Table 1 and activity coefficient of toluene in toluene-DEHA mixtures are given in Fig. 2. The vapor pressures of toluene and DEHA are significantly different, for example at $25^{\circ} \mathrm{C}: P($ toluene $)=3804 \mathrm{~Pa} ; P(\mathrm{DEHA})=7.47 \times 10^{-6} \mathrm{~Pa}$, $P\left(10 \mathrm{~g} \mathrm{~L}^{-1}\right)=80 \mathrm{~Pa}, P\left(1 \mathrm{~g} \mathrm{~L}^{-1}\right)=8 \mathrm{~Pa}$. Even at low concentrations, the toluene vapor pressure is more than a factor $10^{10}$ higher than the DEHA vapor pressure: toluene should be easily extracted from DEHA by pervaporation. This membrane was therefore chosen to extract toluene with a high flux from the liquid phase.

Pervaporation membranes can be divided into three categories according to their use:

- Hydrophilic (water selective) membranes show a high permeability for water and little permeability for organic compounds.

PEG 400, polyethylene 400; DEHA, di(2-ethylhexyl) adipate; DIBP, diisobutyl phthalate. 


\begin{abstract}
- Organophilic (hydrophobic) membranes show good permeation rates for organic molecules but at the expense of low selectivity. Such membranes are used on a technical scale to remove pollutants or recover final products (e.g. of fermentation) from water [8,9]. Only little industrial use has been observed despite the high apparent potential of this technology.

- Organo-selective membranes are able to separate different organic compounds from each other [10]. Applications have mostly been found in the separation of aromatics from aliphatics [11-16] or in isomer separation [17]. This piece of research is included in that category.
\end{abstract}

Since the main target of the considered separation was to remove toluene from the absorbent with the highest rate, membranes allowing toluene to cross easily across the membrane material are required. A literature review showed that PDMS is very permeable for toluene and is an interesting choice from an industrial point of view since it is a stable polymer, produced by a well established film manufacturing technique, and is already successfully used in industrial applications.

PDMS swells considerably on contact with organic solutions due to the solubilization of the molecules in the polymer. This induces several problems for an industrial use: the degradation of the polymer selectivity and a possible loss of the membrane integrity consequent to a non-homogenous and important swelling of the active layer of the membrane. A commercial PDMS membrane was used in order to characterize the pervaporation of toluene from DEHA mixtures.

\section{Modelling}

\subsection{Mass transfer equations}

The pervaporation phenomenon can be represented by a succession of different mechanisms usual in mass transfer systems (Fig. 3): (i) Fick diffusion of the permeate in the liquid boundary layer, (ii) thermodynamic equilibrium of permeate between the

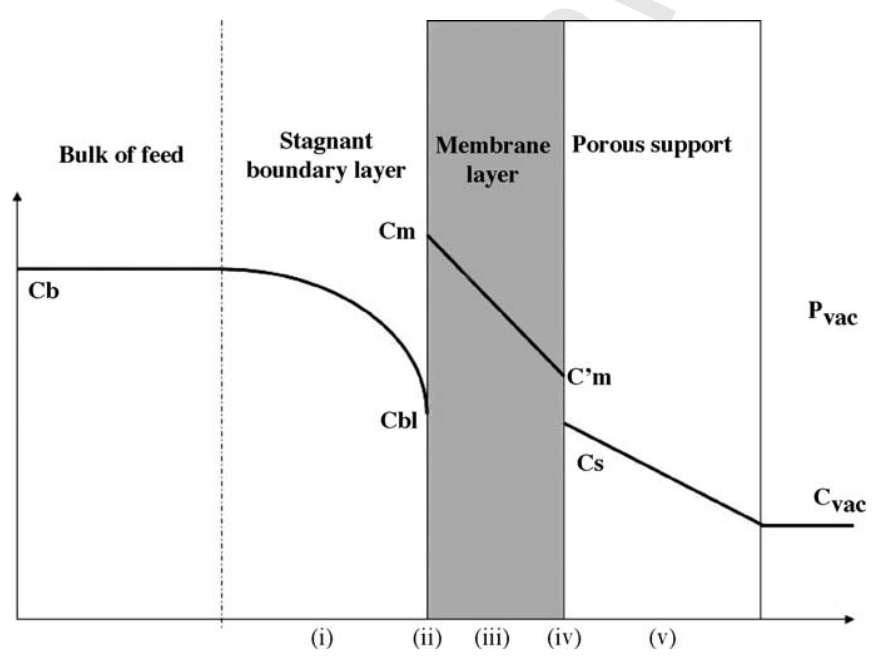

Fig. 3. Concentration profile of the transport phenomenon. liquid and the membrane, (iii) permeate diffusion in the polymer, (iv) thermodynamic equilibrium of permeate between the membrane and the downstream gas phase in the porous media and (v) Knudsen diffusion in the porous media. Both the upstream liquid feed and the downstream vacuum chamber are supposed to be perfectly mixed.

(i) On the membrane surface, a liquid boundary layer depending on the fluid properties and hydrodynamics creates a diffusion area where the mass transfer obeys to the Fickian diffusion of the permeates:

$J=\frac{D_{\mathrm{L}}}{\delta_{\mathrm{bl}}}\left(C_{\mathrm{b}}-C_{\mathrm{bl}}\right)=k_{\mathrm{bl}}\left(C_{\mathrm{b}}-C_{\mathrm{bl}}\right)$

where $J$ is the mass transfer flow rate $\left(\mathrm{kg} \mathrm{m}^{-2} \mathrm{~s}^{-1}\right), D_{\mathrm{L}}$ the diffusion coefficient of the permeate $\left(\mathrm{m}^{2} \mathrm{~s}^{-1}\right), \delta_{\mathrm{bl}}$ the boundary layer thickness (m), $C_{\mathrm{b}}$ and $C_{\mathrm{bl}}$ are the concentration of permeate in the bulk feed and in the boundary layer adjacent to the membrane surface $\left(\mathrm{kg} \mathrm{m}^{-3}\right) . k_{\mathrm{bl}}$ is the mass transfer coefficient $\left(\mathrm{m} \mathrm{s}^{-1}\right)$.

(ii) At the interface between the liquid and the membrane, a thermodynamic equilibrium links the concentration in the liquid phase $C_{\mathrm{bl}}$ to the concentration in the membrane $C_{\mathrm{m}}$ $\left(\mathrm{kg} \mathrm{m}^{-3}\right)$. Partitioning behaviour of a substance penetrating a polymer is usually determined by gas absorption experiments [18]. It is assumed that the sorption isotherms are linear, thus the equilibrium can be described by the solubility $S\left(\mathrm{~kg} \mathrm{~m}^{-3} \mathrm{~Pa}^{-1}\right)$ as follows:

$S=\frac{C_{\mathrm{m}}}{P_{\mathrm{g}}}$

where $P_{\mathrm{g}}(\mathrm{Pa})$ is the pressure in equilibrium with the liquid phase and $C_{\mathrm{m}}\left(\mathrm{kg} \mathrm{m}^{-3}\right)$ is the penetrating concentration into the membrane. De Bo et al. [18] gives the partition coefficient of toluene between gas phase and PDMS: $S=0.0329 \mathrm{~kg} \mathrm{~m}^{-3} \mathrm{~Pa}^{-1}$. The partial pressure on the feed side $P_{\mathrm{g}}$ can be linked to the molar fraction in the feed liquid $\mathrm{x}$ by the formula:

$P_{\mathrm{g}}=\gamma \cdot x \cdot P^{\mathrm{sat}}$

where $\gamma$ is the activity coefficient of the permeate in the liquid and $P^{\text {sat }}$ is the saturation vapor pressure of the permeate. Combining Eqs. (3) and (4) yields:

$C_{\mathrm{m}}=S \cdot \gamma \cdot P^{\mathrm{sat}} x$

Thus, the permeate will increasingly be absorbed in the membrane polymer if the activity coefficient of the permeate in the feed liquid is higher. This is the effect of the repulsion of the liquid solvent which increases the solubilization of the species to pervaporate into the membrane polymer. The activity coefficient of toluene is 0.50 in DEHA, 0.88 in DIBP and 1.23 in PEG 400 [5]. Toluene will consequently be more absorbed in PDMS in the case of a solution with PEG 400.

Practically, it is more convenient to use Henry's law where it can be applied, i.e. where the equilibrium can be represented by a line: $P_{\mathrm{g}}=H \cdot C_{\mathrm{bl}}, H$ is the Henry's coefficient. A 
previous paper [5] reported that $H_{\mathrm{DEHA}}=7.74 \mathrm{~Pa} \mathrm{~kg}^{-1} \mathrm{~m}^{3}$; $H_{\text {DIBP }}=9.73 \mathrm{~Pa} \mathrm{~kg}^{-1} \mathrm{~m}^{3}$ and $H_{\text {PEG400 }}=15.27 \mathrm{~Pa} \mathrm{~kg}^{-1} \mathrm{~m}^{3}$.

(iii) The diffusion in the membrane polymer obeys Fick's law:

$J=\frac{D_{\mathrm{M}}}{\delta_{\mathrm{M}}}\left(C_{\mathrm{m}}-C_{\mathrm{m}^{\prime}}\right)=k_{\mathrm{m}}\left(C_{\mathrm{m}}-C_{\mathrm{m}^{\prime}}\right)$

where $C_{\mathrm{m}^{\prime}}\left(\mathrm{kg} \mathrm{m}^{-3}\right)$ is the concentration in the polymer on the vacuum side. The diffusivity $D_{\mathrm{M}}$ depends on the swelling of the polymeric material in the case of rubbery polymers.

(iv) The thermodynamic equilibrium between the membrane polymer and the vacuum side can be described with Eq. (3).

(v) The Knudsen diffusion may play a limiting role in the overall mass transfer.

\subsection{Boundary layer}

The boundary layer effect is characteristic of all membrane processes. This boundary layer is represented by a stagnant fluid adjacent to the membrane surface. All permeating compounds must cross this layer in which the transfer is diffusive. The consequence is that the boundary layer can significantly affect the overall permeation efficiency of the process, especially in case of viscous liquids. Determining the effect of the boundary layer requires knowing its thickness $\delta_{\mathrm{bl}}$. It is difficult to obtain accurate predictions for this parameter using existing dimensionless correlations. The usual way to calculate the boundary layer thickness $\delta_{\mathrm{bl}}$ is to calculate the Sherwood number $S h=k_{\mathrm{b} 1} \cdot d_{\mathrm{h}} / D_{\mathrm{L}}$, where $d_{\mathrm{h}}$ is the hydraulic diameter of the device. The Sherwood number is calculated from Reynolds number $R e=\rho \cdot U \cdot d_{\mathrm{h}} / \mu$ and the Schmidt number $S c=\mu / \rho \cdot D_{\mathrm{L}}$ according to the equation:

$S h=a \operatorname{Re}^{b} S c^{c}\left(\frac{d_{\mathrm{h}}}{L}\right)^{d}$

where $L$ is the total effective membrane length. As pointed out by Hickey and Gooding [19], the main problem is the definition of the characteristic dimension (i.e. the hydraulic diameter $d_{\mathrm{h}}$ ) of a feed flow channel in the case of special pervaporation modules such as the one used in this work. Thus, it is preferable to extract values from experimental data. A common approach to obtain values for $k_{\mathrm{bl}}$ is to use the data of $J$ obtained from pervaporation experiments and to plot the results as a function of different membrane thicknesses. This way, the mass transfer resistance of the boundary layer can be determined and the $k_{\mathrm{bl}}$ value deducted. Another method is to use the resistances-in-series model.

\subsection{Resistances-in-series model}

A convenient representation of the overall mass transfer is the resistances-in-series model, in which the overall resistance to transport is the sum of the boundary layer resistance, the membrane resistance and the support layer resistance. The overall mass transfer flow rate can be expressed with the pressure drop as the driving force with an overall mass transfer coefficient $K_{\mathrm{ov}}$. The pressures are taken as the vapor pressure in equilibrium with the liquid phase on the liquid phase $P_{\mathrm{b}}$ and the vacuum phase $P_{\text {vac. }}$. The overall mass transfer flow rate can then be written as:

$J=K_{\mathrm{ov}} \cdot\left(P_{\mathrm{b}}-P_{\mathrm{vac}}\right)$

The following equation is commonly used to represent the resistances-in-series model:

$J=\frac{1}{R_{\mathrm{ov}}}\left(P_{\mathrm{b}}-P_{\mathrm{vac}}\right)$

This model is called resistances-in-series because it enables to add the resistances of all mass transfer steps:

$R_{\mathrm{ov}}=R_{\mathrm{bl}}+R_{\mathrm{m}}+R_{\mathrm{S}}$

where $R_{\mathrm{ov}}, R_{\mathrm{bl}}, R_{\mathrm{m}}$ and $R_{\mathrm{S}}\left(\mathrm{Pa} \mathrm{m}^{2} \mathrm{~s}^{1} \mathrm{~kg}^{-1}\right.$, equivalent to $\left.\mathrm{m} \mathrm{s}^{-1}\right)$ are respectively the resistances of the boundary layer, the membrane and the support. Remembering that Eq. (1) can be written as:

$J=k_{\mathrm{bl}}\left(C_{\mathrm{b}}-C_{\mathrm{bl}}\right)=\frac{k_{\mathrm{bl}}}{H}\left(P_{\mathrm{b}}-P_{\mathrm{bl}}\right)$

Eq. (5) can be written as:

$J=k_{\mathrm{M}} \cdot\left(C_{\mathrm{m}}-C_{\mathrm{m}^{\prime}}\right)=S \cdot k_{\mathrm{M}}\left(P_{\mathrm{b} 1}-P_{\mathrm{s}}\right)$

If gas concentrations are used instead of partial pressures, $J$ can be written thanks to the membrane permeability:

$$
\begin{aligned}
J & =S \cdot k_{\mathrm{M}}\left(P_{\mathrm{bl}}-P_{\mathrm{s}}\right)=\frac{R T}{M} S \cdot k_{\mathrm{M}}\left(C_{\mathrm{G}, \mathrm{bl}}-C_{\mathrm{G}, \mathrm{s}}\right) \\
& =P\left(C_{\mathrm{G}, \mathrm{bl}}-C_{\mathrm{G}, \mathrm{s}}\right)
\end{aligned}
$$

$P$ is the permeability $\left(\mathrm{m}^{2} \mathrm{~s}^{-1}\right)$ of the membrane and $C_{\mathrm{G}}$ are the mass concentrations $\left(\mathrm{g} \mathrm{m}^{-3}\right)$ in the gas phases.

Finally,

$R_{\mathrm{bl}}=\frac{H \cdot \delta_{\mathrm{bl}}}{D_{\mathrm{L}}}=\frac{H}{k_{\mathrm{bl}}}$

$R_{\mathrm{m}}=\frac{\delta_{\mathrm{M}}}{S \cdot D_{\mathrm{M}}}=\frac{1}{S \cdot k_{\mathrm{M}}}$

This theory presents the clear advantage to show the influence of the different parameters: diffusion into the liquid $D_{\mathrm{L}}$ and into the membrane $D_{\mathrm{M}}$, hydrodynamics in the liquid boundary layer $\left(\delta_{\mathrm{bl}}\right)$, thickness of the membrane $\left(\delta_{\mathrm{M}}\right)$ and thermodynamic equilibriums of toluene between the liquid and gas phases $H$ or the membrane polymer and gas phase $S$.

\section{Materials and methods}

Two pervaporation modules were used to carry out the experiments: a planar module and a tubular module. For the sake of simplicity, both pervaporation modules could be used on a common experimental apparatus, simply by changing the tube connections. Fig. 4 shows a diagram of the experimental apparatus.

A preparation of absorbent containing a fixed concentration of toluene was thermostated in a double walled container (3). This liquid was pumped into the pervaporation module (1) by means of a centrifugal pump (2). A vacuum was applied to the 


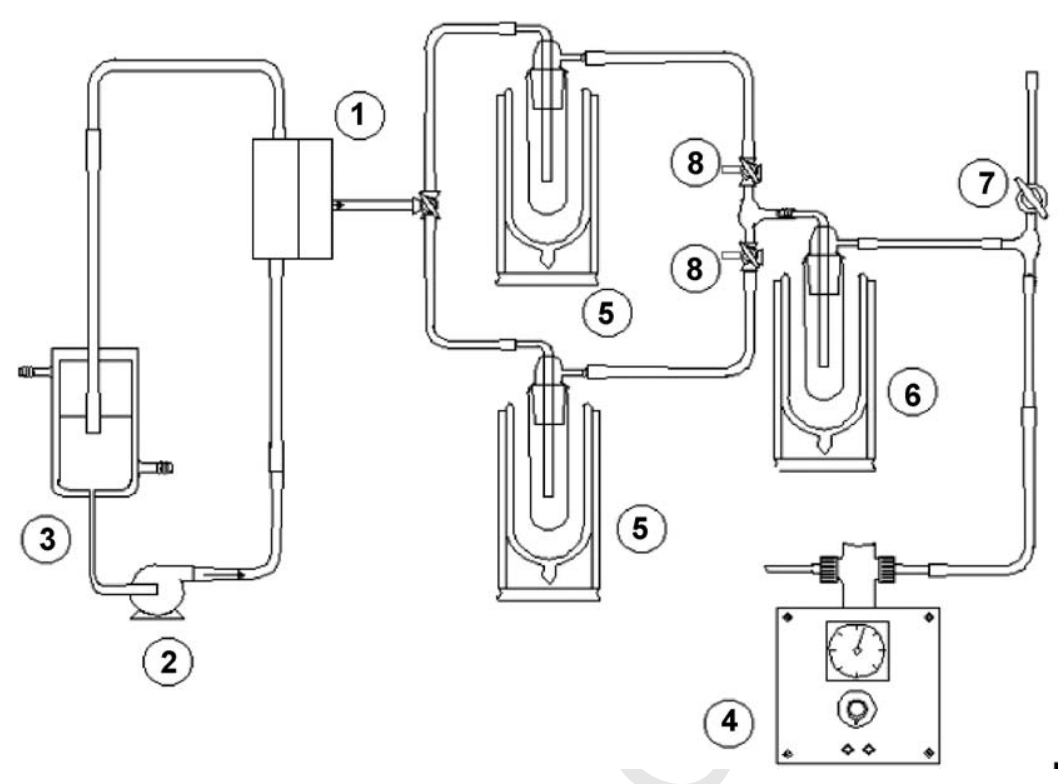

Fig. 4. Pervaporation device flow diagram.

downstream section by means of a vane pump (4). The permeates condensed by liquid nitrogen were alternately recovered in cold traps (5). The vacuum pump was protected by an additional cold trap (6). The level of vacuum was fixed by means of the regulator valve (7). For weighing purposes, the vacuum in the cold traps could be broken by the two three-way control valves (8). The pervaporate was thus recovered in batches, using two cold traps on an alternating basis.

Two cell geometries were chosen in order to study different geometries and mass transfer resistance upstream of the membrane: a flat and a tubular geometry. The start-up protocol consisted of five steps: (i) preparation of the solution to be treated, placement in the thermostated container and closure of the opening, (ii) start-up of the pump and circulation of the warm-up liquid in the double skin, (iii) after stabilization of the temperature, application of a vacuum to two pervaporation traps, (iv) once the vacuum applied, immersion of the traps in the cold traps filled with liquid nitrogen $\left(-196^{\circ} \mathrm{C}\right)$, the nitrogen levels were topped up once the cold traps reached the correct temperature, (v) opening of the vacuum valve of the module, starting of chronometer. The traps were changed regularly using the three-way valves (8) and immediately closed with Parafilm. Once they reached ambient temperature, they were wiped and weighed. The samples contained in the traps were washed in a known mass of ethanol in order to recover all the condensates in hermetic flasks. Samples were then analysed by UV and FTIR spectroscopy.

Experiments were carried out with pure toluene, pure absorbents and mixtures of toluene with the different absorbents. In the case of pure toluene, cold traps were changed every $10 \mathrm{~min}$ and each experiment lasted $1 \mathrm{~h}$. In case of pure absorbents, cold traps were changed every hour and each experiment lasted $6 \mathrm{~h}$. In case of the mixtures, cold traps were changed every $30 \mathrm{~min}$ and each experiment lasted $6 \mathrm{~h}$. All experiments were repeated once. The first flow rates were not taken into account because they corresponded to a transitory regime. Once the measured flow rates were stable, an average value was calculated for all remaining cold traps and then compared to the repeated experiment.

Toluene concentrations to investigate were chosen in accordance to a real absorbent solution concentration at the bottom of an absorption column. Studies done on an experimental absorption tower treating an exhaust gas $\left(25^{\circ} \mathrm{C}\right)$ charged with toluene at $3.7 \mathrm{~g} \mathrm{~m}^{-3}$ give a maximum concentration (thermodynamic equilibrium) of $13.20 \mathrm{~g} \mathrm{~L}^{-1}$ (DEHA), $10.60 \mathrm{~g} \mathrm{~L}^{-1}$ (DIBP) and $6.80 \mathrm{~g} \mathrm{~L}^{-1}$ (PEG 400). The concentration range in liquid phase to regenerate was therefore chosen as $\left(1-10 \mathrm{~g} \mathrm{~L}^{-1}\right)$.

\subsection{Plane pervaporation cell}

The first pervaporation device was provided by SEMPASS (model QFZ30, Germany) (Fig. 5). It consists of two compartments separated by the membrane. The $55 \mathrm{~cm}^{2}$ membrane (1) is mounted on a porous metallic support (2), thickness $5 \mathrm{~mm}$, pore diameter $100 \mu \mathrm{m}$. The feed flow (3) ran radially through the pervaporation cavity and the solvent was recovered from the top of the module (4). A vacuum was applied to the lower part of the module (5) and the pervaporate was recovered from the side (6). The module could be split into two parts in order to change the membrane, with a Viton O-ring and a circular clamp to ensure water tightness. It should be noted that the top of the pervaporation cavity had a hyperbolic metallic surface, thus maintaining a constant tangential speed whatever the radial position considered on the membrane. The particular configuration of the module (symmetry and variable thickness) meant that the hydraulic diameter could not be calculated in the usual way. The manufacturer gave the hydraulic diameter as $1.1 \mathrm{~mm}$ and indicated that the formula giving the tangential speed as a function of the flow rate is written as: $U_{\mathrm{L}}=8580 \times Q_{\mathrm{L}}$, where $U_{\mathrm{L}}$ is the tangential circulation velocity $\left(\mathrm{m} \mathrm{s}^{-1}\right)$ and $Q_{\mathrm{L}}$ is the volumic flow rate $\left(\mathrm{m}^{3} \mathrm{~s}^{-1}\right)$.

The membrane used was a Sulzer PERVAP 1060 ChemTech sheet consisting of two parts (i) an active layer $(20 \mu \mathrm{m})$ in 

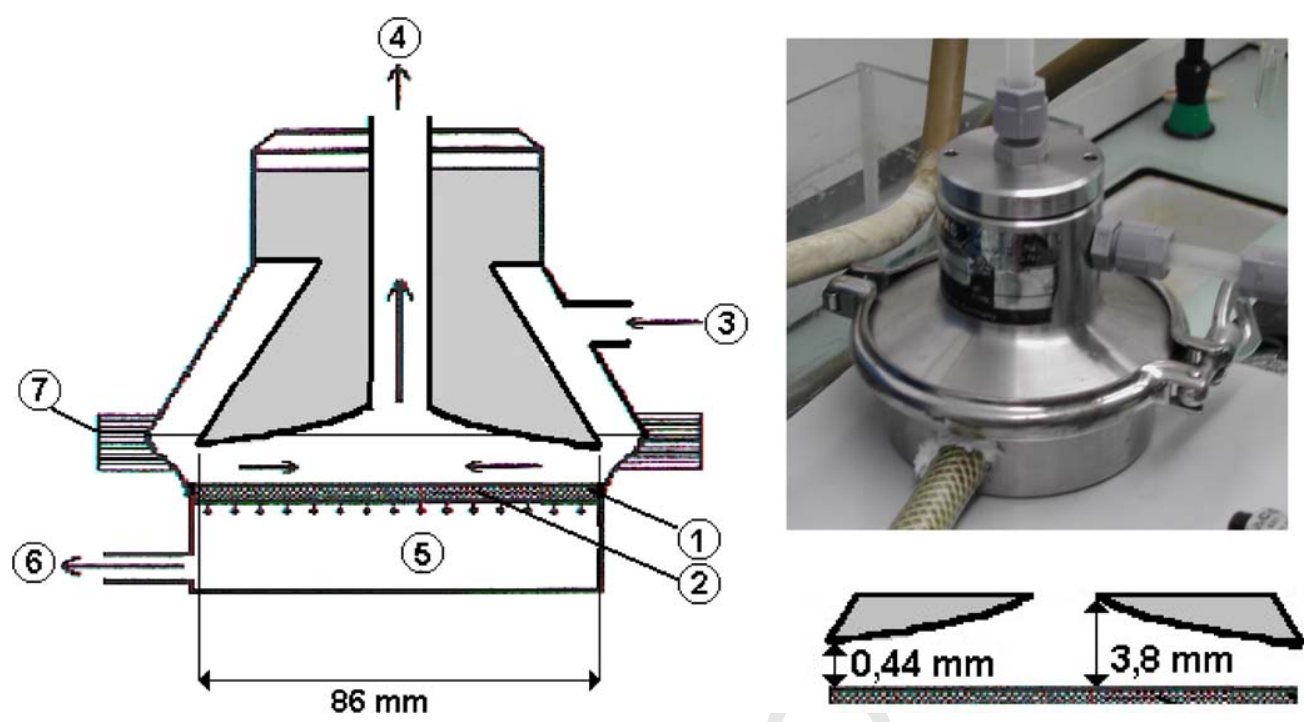

Fig. 5. Planar pervaporation device.

PDMS, which was put in direct contact with the input to be treated; (ii) a macroporous polyacrylonitrile (PAN) supporting layer $(250 \mu \mathrm{m})$, to ensure the mechanical characteristics of the membrane.

\subsection{Tubular pervaporation cell}

The tubular module (Fig. 6) was provided by Pervatech BV (model PVM-250-10-1-250 RPV/G, The Netherlands). A separating layer of PDMS (1) was deposited on the inside surface of a tubular silica-based ceramic support (2). The liquid to be treated (3), (4) flowed inside a tube of interior diameter $7 \mathrm{~mm}$ and length $250 \mathrm{~mm}$, giving an active surface area of $55 \mathrm{~cm}^{2}$. A vacuum was applied to the filter body of the tube (5) by means of a lateral outlet (6). The module could also function by flushing with an inert vector gas, entering the filter body through another inlet (7), which was hermetically sealed for our experiments. The formula giving the tangential speed in function of the flow is written as: $U_{\mathrm{L}}=$ $25,984 \times Q_{\mathrm{L}}$.

The manufacturer indicated that the membrane is made up of a series of four deposited layers: (i) an alpha- $\mathrm{AlO}_{2}$ alumina support layer, thickness $1.5 \mathrm{~mm}$, pore diameter $3 \mu \mathrm{m}$ (ii) a first alpha- $\mathrm{AlO}_{2}$ alumina layer, thickness $50 \mu \mathrm{m}$, pore diameter $0.5 \mu \mathrm{m}$ (iii) a second alpha- $\mathrm{AlO}_{2}$ alumina layer, thickness $30 \mu \mathrm{m}$, pore diameter $0.1 \mu \mathrm{m}$, (iv) a third alpha- $\mathrm{AlO}_{2}$ alumina layer, thickness $2 \mu \mathrm{m}$, pore diameter $0.2 \mu \mathrm{m}$, and (v) a fourth layer, thickness $2 \mu \mathrm{m}$, the selective PDMS barrier.

\section{Results and discussion}

\subsection{Pure toluene pervaporation}

A pervaporation experiment using pure toluene was carried out for each membrane. The average flow rates obtained were $1.5 \mathrm{~kg} \mathrm{~h}^{-1} \mathrm{~m}^{-2}$ for the tubular membrane and $2.8 \mathrm{~kg} \mathrm{~h}^{-1} \mathrm{~m}^{-2}$ for the planar membrane $\left(P_{\mathrm{vac}}=1 \mathrm{mbar}\right.$ and $\left.T=25^{\circ} \mathrm{C}\right)$. Since no liquid boundary layer can occur, these values allow calculation of the permeability of the two membranes: $P=1.13 \times 10^{-7} \mathrm{~m}^{2} \mathrm{~s}^{-1}$ with the flat 1060 membrane and $P=6.04 \times 10^{-9} \mathrm{~m}^{2} \mathrm{~s}^{-1}$ with the tubular membrane. The value of the PERVAP membrane is close to literature values: Boscaini et al. proposed a permeability of $2.07 \times 10^{-7} \mathrm{~m}^{2} \mathrm{~s}^{-1}$ [20] at $30^{\circ} \mathrm{C}$ with a hollow fiber membrane made of PDMS.

This permeability difference could result from a different PDMS layer (not given by the manufacturer) or from the limiting effect of the porous support which has been shown by previous observations [21]. The pores of the ceramic support $(\leq 3 \mu \mathrm{m})$ are smaller than those of the porous support of the flat membrane $(200 \mu \mathrm{m})$. Because of this permeability difference, future results will be presented about the Pervap 1060 membrane.

\subsection{Pure absorbent pervaporation}

Pervaporation experiments were carried out using pure absorbents (DEHA, DIBP, PEG 400) in order to measure their ability to cross the membrane.
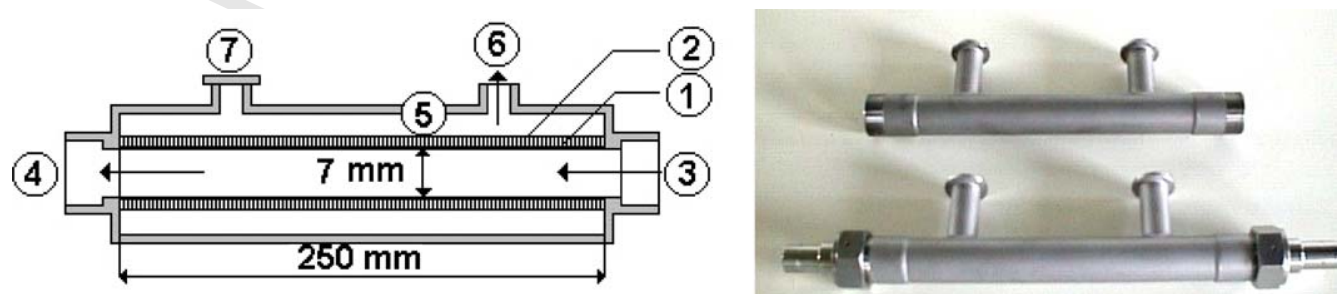

Fig. 6. Tubular pervaporation device. 
Table 2

Toluene pervaporation fluxes for 100 and $10 \mathrm{~g} \mathrm{~L}^{-1}$ solutions

\begin{tabular}{llll}
\hline Absorbent & $\begin{array}{l}\text { Feed toluene } \\
\text { concentration } \\
C_{\mathrm{b}}\left(\mathrm{g} \mathrm{L}^{-1}\right)\end{array}$ & Temperature $\left({ }^{\circ} \mathrm{C}\right)$ & $\begin{array}{l}\text { Average } \\
\text { pervaporation flow } \\
\text { rate } J\left(\mathrm{~g} \mathrm{~m}^{-2} \mathrm{~h}^{-1}\right)\end{array}$ \\
\hline DEHA & 100 & 25 & 159 \\
DIBP & 100 & 25 & 80 \\
PEG 400 & 100 & 25 & 85 \\
DEHA & 10 & 25 & 17 \\
DIBP & 10 & 25 & 5 \\
PEG 400 & 10 & 25 & 3.5 \\
\hline
\end{tabular}

An average flow rate of $1.9 \mathrm{~g} \mathrm{~h}^{-1} \mathrm{~m}^{-2}$ was measured for the pervaporation of pure DEHA, $2.9 \mathrm{~g} \mathrm{~h}^{-1} \mathrm{~m}^{-2}$ in the case of pure DIBP and nothing was measured with pure PEG 400. These results show that the absorbents cross the membrane to a very limited extent, which is promising for their regeneration by pervaporation. It can be noticed that PEG 400 was not detected at all in the permeate.

Solubility parameters were calculated for all absorbents. The corresponding value for $\Delta$ is $1 \mathrm{cal} \mathrm{cm}^{-3}$ for DEHA-PDMS, $0.01 \mathrm{cal} \mathrm{cm}^{-3}$ for DIBP-PDMS and $1 \mathrm{cal} \mathrm{cm}^{-3}$ for PEG 400-PDMS. Theses values show that $\Delta$ values are not sufficient to explain the pervaporation flow rates of such absorbents. Indeed, the effects of the diffusion in the membrane material are predominant.

Since all absorbents have a high boiling point, condensation onto the porous support could occur on the vacuum side. This point was verified experimentally by $50 \mathrm{~h}$ with pure DEHA and by weighing the porous support each $10 \mathrm{~h}$. Results gave a stable average flow rate of $21 \mathrm{~g} \mathrm{~h}^{-1} \mathrm{~m}^{-2}$ which should be added to the permeate flow rate collected in the cold traps in the case of pure DEHA pervaporation. This implies an important consequence: the support layer will gradually be filled with DEHA and the toluene flow rate will drastically decrease due to the wetted porous support resistance.

\subsection{Mixture pervaporation}

Previous data about pure components show that toluene permeates more than 100 times faster than pure absorbents. It is nonetheless necessary to verify experimentally the pervaporation of toluene while contained in the different absorbents. Two kinds of toluene enriched absorbent solutions were made and tested with the planar membrane: a set of solutions enriched with $100 \mathrm{~g} \mathrm{~L}^{-1}$ of toluene and a set enriched with $10 \mathrm{~g} \mathrm{~L}^{-1}$ of toluene. Experiments were carried out at $25^{\circ} \mathrm{C}$, vacuum pressure was $100 \mathrm{~Pa}$ and the liquid velocity was kept constant for all

experiments $\left(1.8 \mathrm{~m} \mathrm{~s}^{-1}\right)$. The different flow rates corresponding to the cold traps weights were stable and an average could be calculated. Values are presented in Table 2.

Analyses did not detect the presence of absorbent in the samples, which indicates that the swelling of the PDMS membrane due to toluene inclusion in the polymeric chains did not greatly increase the absorbent pervaporation flow rate. With regards to toluene flow rates, DEHA proved to be the most easily regenerable solvent, with a much higher toluene extraction flow rate than those observed with DIBP or PEG 400, which goes contrary to the thermodynamic fact that PEG 400 promotes toluene absorption into the membrane. According to that conclusion, all following experiments were carried with DEHA.

\subsection{PDMS active layer and support layer resistances}

Experiments were carried out to evaluate the influence of the PDMS active layer and of the porous support on the toluene flux. To achieve that goal, three different configurations were used in the same operating conditions during $6 \mathrm{~h}$. Table 3 summarizes the results. All flow rates are similar which leads to the conclusion that the main resistance is located with the boundary liquid effect This is not surprising since DEHA is a viscous liquid.

\subsection{Influence of liquid velocity}

Twelve experiments at different shear velocities were carried out with DEHA in the planar module. The measured flow rates are listed in Table 4. An increase in the velocity of the liquid led to an increase in the pervaporation flow, which highlights the key role of the liquid boundary layer. The regime is laminar, even in the case of higher speeds $(R e \leq 400)$. By considering that no support layer resistance occurs, results allowed the calculation of the mass transfer coefficient $k_{\mathrm{bl}}$ and Sherwood numbers through the liquid boundary layer. $\ln (S h)$ versus $\ln (R e)$ is plotted in Fig. 7. The good correlation of the points confirms that the pervaporation flows are essentially limited by the laminar boundary layer. The power of the Reynolds number is 0.51 which is different from the Levesque's Reynolds power (1/3). This translates the special hydrodynamics in the radial hyperbolic fluid flow in the SEMPASS pervaporation module.

\subsection{Influence of temperature}

Experiments with DEHA were performed to evaluate the influence of temperature. Temperature variations applied to pure toluene and a DEHA-toluene mixture $\left(9 \mathrm{~g} \mathrm{~L}^{-1}\right)$, increased greatly the toluene fluxes recovered downstream (Fig. 8).

Table 3

Influence of the PDMS thickness and the porous support pore size

\begin{tabular}{|c|c|c|c|c|}
\hline $\begin{array}{l}\text { Feed toluene } \\
\text { concentration } C_{\mathrm{b}}\left(\mathrm{g} \mathrm{L}^{-1}\right)\end{array}$ & Temperature $\left({ }^{\circ} \mathrm{C}\right)$ & $\begin{array}{l}\text { PDMS active layer } \\
\text { thickness }(\mu \mathrm{m})\end{array}$ & $\begin{array}{l}\text { Porous support layer } \\
\text { pore diameter }(\mu \mathrm{m})\end{array}$ & $\begin{array}{l}\text { Average pervaporation } \\
\text { flow rate } J\left(\mathrm{~g} \mathrm{~m}^{-2} \mathrm{~h}^{-1}\right)\end{array}$ \\
\hline 4.6 & 48 & 20 & 200 & 5.1 \\
\hline 4.6 & 48 & 20 & 50 & 4.9 \\
\hline 4.6 & 48 & 40 & 200 & 5.0 \\
\hline
\end{tabular}


Table 4

Influence of the liquid velocity

\begin{tabular}{|c|c|c|c|c|}
\hline $\begin{array}{l}\text { Liquid velocity } \\
\left(\mathrm{m} \mathrm{s}^{-1}\right)\end{array}$ & $\begin{array}{l}\text { Reynolds } \\
\text { number } R e\end{array}$ & $\begin{array}{l}\text { Feed toluene } \\
\text { concentration } C_{\mathrm{b}}\left(\mathrm{g} \mathrm{L}^{-1}\right)\end{array}$ & Temperature $\left({ }^{\circ} \mathrm{C}\right)$ & $\begin{array}{l}\text { Average pervaporation } \\
\text { flow rate } J\left(\mathrm{~g} \mathrm{~m}^{-2} \mathrm{~h}^{-1}\right)\end{array}$ \\
\hline 0.34 & 102 & 4.6 & 48 & 3.8 \\
\hline 0.60 & 176 & 4.6 & 48 & 5.1 \\
\hline 0.95 & 282 & 4.6 & 48 & 6.2 \\
\hline 0.34 & 102 & 6.3 & 48 & 5.0 \\
\hline 0.60 & 176 & 6.3 & 48 & 6.8 \\
\hline 0.95 & 282 & 6.3 & 48 & 8.6 \\
\hline 0.34 & 102 & 10.7 & 48 & 8.4 \\
\hline 0.60 & 176 & 10.7 & 48 & 11.1 \\
\hline 1.30 & 388 & 10.7 & 48 & 16.9 \\
\hline
\end{tabular}

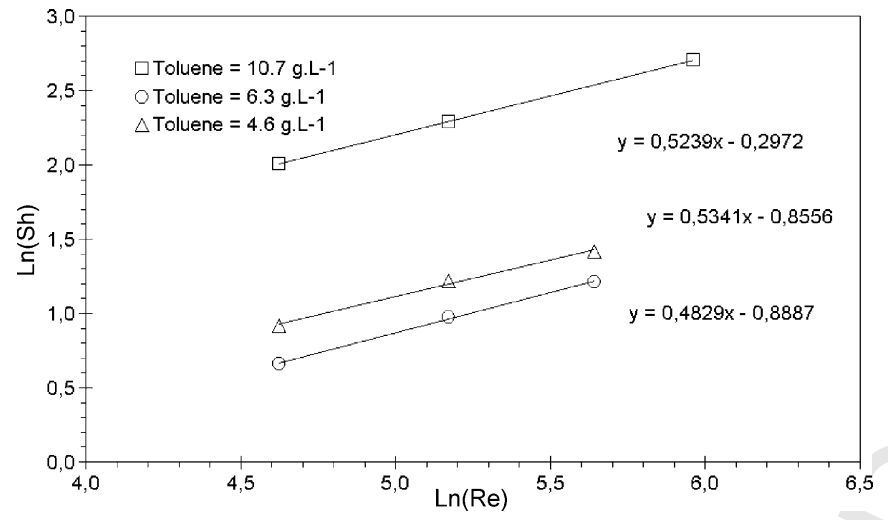

Fig. 7. Sherwood number vs. Reynolds number $\left(25^{\circ} \mathrm{C}\right)$.

We observed a different value for the activation energy of the pervaporation flow for pure toluene in PDMS $\left(78.231 \mathrm{~kJ} \mathrm{~mol}^{-1}\right)$ and for a toluene concentration of $9 \mathrm{~g} \mathrm{~L}^{-1}\left(23.025 \mathrm{~kJ} \mathrm{~mol}^{-1}\right)$. This apparent activation energy difference probably results from a temperature polarization on the liquid side. This phenomenon occurs when the permeates require an important heat of vaporization coupled with high pervaporation fluxes, and is promoted when bad hydrodynamics create an important boundary layer on the membrane surface [22].

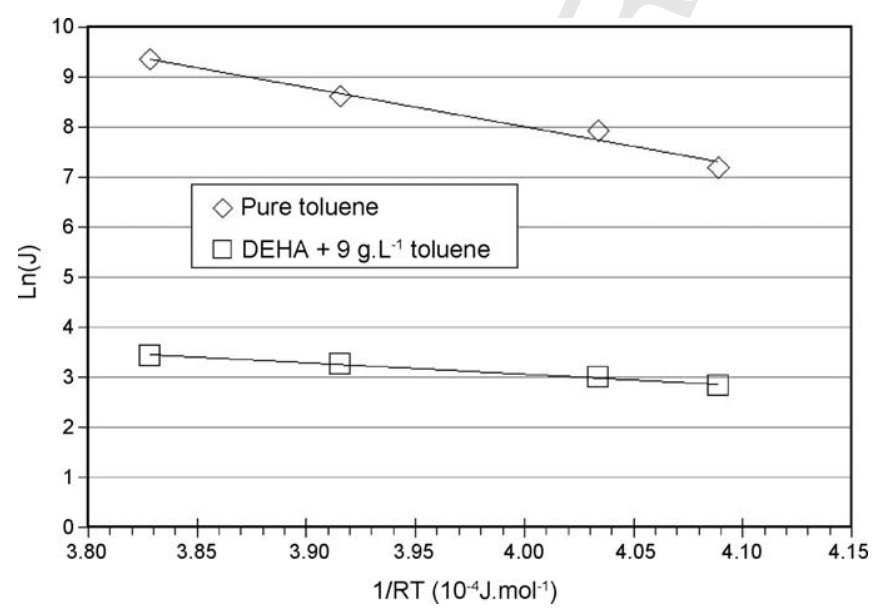

Fig. 8. Influence of temperature on the pervaporation flow rate.
Understanding the meaning of the activation energy is not simple and involves several phenomena. Literature data [20] enable to calculate the permeability of a PDMS membrane as a function of temperature (Fig. 9). The experimental permeability proposed by Leeman et al. [23] was added for comparison. The permeability of the PDMS membrane decreases when the temperature increases although the diffusivity is higher. This is due to the unfavorable influence of the temperature on the sorption equilibrium of toluene in PDMS. However, increasing temperature will increase the vapor pressure of toluene in equilibrium with DEHA mixtures. Calculations were done to calculate the overall flux for $x=0.01,0.005$ and 0.001 with the hypothesis of no thermal boundary layer. Results are shown in Fig. 9. These theoretical behaviours follow the usual log-law, and a linear regression of $\ln (J)$ versus $1 / R T$ allowed calculation of the activation energy. For $x=0.04\left(\sim 9 \mathrm{~g} \mathrm{~L}^{-1}\right)$, the calculated activation energy is $E_{\mathrm{a}}=31.356 \mathrm{~kJ} \mathrm{~mol}^{-1}$, which has to be compared with the apparent activation energy measured during the experiments: $E_{\mathrm{a}}=23.025 \mathrm{~kJ} \mathrm{~mol}^{-1}$. According to Favre [22] this activation energy could result from the temperature polarization.

To verify if polarization occurs, it is interesting to change the liquid velocity while pervaporating a pure liquid. Since no mass transfer boundary occurs, hydrodynamic changes while increasing liquid velocity results in a temperature polarization decrease [22]. This was done with pure DEHA, but no change was observed.

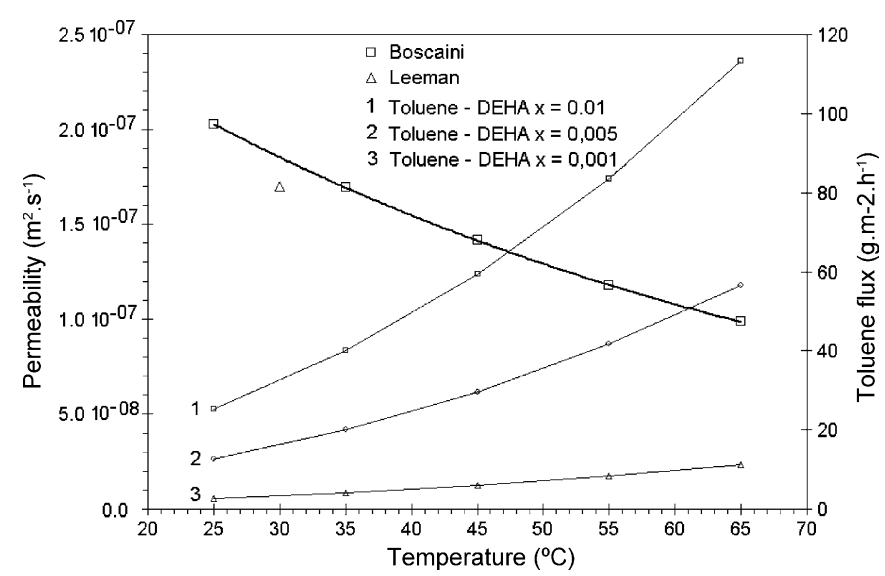

Fig. 9. Influence on temperature on toluene permeability and on the theoretical toluene flow rates.

\section{(1)}

(1)




\section{Conclusion}

Bibliographical research and a preliminary theoretical evaluation led to the choice of PDMS for separating the toluene/absorbent mixture, whatever the absorbent. PDMS has a high affinity for toluene and a lower affinity for the different absorbents. The permeability of the toluene was evaluated at $25^{\circ} \mathrm{C}$ and confirmed the potential of PDMS for recovering toluene. Experiments led with the various pure absorbents showed that no absorbent was detected in the filtrates. The presence of absorbent in the filtrate was only detected in the case of the pervaporation of pure solvents. An experiment carried out on a long period with DEHA showed that DEHA accumulates in the porous support. This could happen with the other absorbents but was not investigated in this work. This is a major point which should be carefully considered. In the case of toluene-absorbent mixtures $\left(10 \mathrm{~g} \mathrm{~L}^{-1}\right)$, results led to the conclusion that DEHA would be the most easily regenerable absorbent. The toluene flows extracted were considerably higher that those measured using DIBP or PEG 400.

Experimental pervaporation flows at low toluene concentrations $\left(<10 \mathrm{~g} \mathrm{~L}^{-1}\right)$ were very low. The predominant effect of the liquid boundary layer was highlighted. The resistance-in-series theory enabled the impact of the boundary layer to be quantified. Liquid hydrodynamics upstream of the membrane therefore seem to be the major parameter. The tubular module was intended to study this question rigorously, but the experiments could not be carried out due to the module being accidentally damaged.

Pervaporation was investigated to regenerate a heavy boiling absorbent containing toluene at low concentrations $\left(<10 \mathrm{~g} \mathrm{~L}^{-1}\right)$. This process was chosen because of thermal decomposition of heavy absorbents by distillation and absorbent loss by stripping. This work showed that the separation by pervaporation could be achieved. However, several problems were highlighted: strong boundary layer effects on the mass and heat transfer and accumulation of absorbent in the porous support. These reasons discourage the use of pervaporation for the considered purpose and other solutions have to be investigated.

\section{Acknowledgements}

This work was carried out with the financial support of the ADEME (Agence de l'Environnement et de la Maîtrise de l'Energie, France) and the Europe Environnement company (Vieux Thann, France).

\section{Nomenclature}

$C_{\mathrm{b}} \quad$ concentration into the bulk of the fluid $\left(\mathrm{kg} \mathrm{m}^{-3}\right)$

$C_{\mathrm{bl}} \quad$ concentration into the boundary layer $\left(\mathrm{kg} \mathrm{m}^{-3}\right)$

$C_{\mathrm{m}}, C_{\mathrm{m}^{\prime}}$ concentration in the membrane on the liquid or the vacuum interface $\left(\mathrm{kg} \mathrm{m}^{-3}\right)$

$d_{\mathrm{h}} \quad$ hydraulic diameter $(\mathrm{m})$
$D_{\mathrm{L}} \quad$ diffusion coefficient of toluene into the absorbents $\left(\mathrm{m}^{2} \mathrm{~s}^{-1}\right)$

$D_{\mathrm{M}} \quad$ diffusion coefficient of toluene into the membrane $\left(\mathrm{m}^{2} \mathrm{~s}^{-1}\right)$

$H \quad$ Henry's coefficient $\left(\mathrm{Pa} \mathrm{m}^{3} \mathrm{~g}^{-1}\right)$

$J \quad$ pervaporation flow rate $\left(\mathrm{kg} \mathrm{s}^{-1} \mathrm{~m}^{-2}\right)$

$k_{\mathrm{bl}} \quad$ mass transfer coefficient $\left(\mathrm{m} \mathrm{s}^{-1}\right)$

$M \quad$ molar weight of toluene $\left(\mathrm{g} \mathrm{mol}^{-1}\right)$

$P \quad$ permeability $\left(\mathrm{m}^{2} \mathrm{~s}^{-1}\right)$

$P_{\mathrm{g}} \quad$ partial pressure $(\mathrm{Pa})$

$P^{\text {sat }} \quad$ saturation vapor pressure $(\mathrm{Pa})$

$Q_{\mathrm{L}} \quad$ liquid flow rate $\left(\mathrm{m}^{3} \mathrm{~h}^{-1}\right)$

$R \quad$ perfect gas coefficient $\left(=8.31441 \mathrm{~J} \mathrm{~mol}^{-1} \mathrm{~K}^{-1}\right)$

$S \quad$ solubility of a penetrant into a polymer $\left(\mathrm{kg} \mathrm{m}^{-3} \mathrm{~Pa}^{-1}\right)$

$t \quad$ experiment time $(\mathrm{h})$

$T$ temperature (K)

$U_{\mathrm{L}} \quad$ liquid velocity $\left(\mathrm{m} \mathrm{s}^{-1}\right)$

\section{Greek letters}

$\delta_{\mathrm{bl}} \quad$ boundary layer thickness $(\mathrm{m})$

$\delta \quad$ solubility parameter $\left(\mathrm{cal} \mathrm{cm}^{-3}\right)^{1 / 2}$

$\delta_{\mathrm{S}} \quad$ solubility parameter of the solvent $\left(\mathrm{cal} \mathrm{cm}^{-3}\right)^{1 / 2}$

$\delta_{\mathrm{M}}$ solubility parameter of the membrane $\left(\mathrm{cal} \mathrm{cm}^{-3}\right)^{1 / 2}$

$\delta_{\text {toluene }}$ solubility parameter of toluene $\left(\mathrm{cal} \mathrm{cm}^{-3}\right)^{1 / 2}$

$\gamma \quad$ activity coefficient

\section{Subscripts}

b bulk of the fluid

bl boundary layer

m membrane

vac vacuum side

\section{References}

[1] T.K. Poddar, Membrane-based absorption of VOCs from a gas stream, AIChE J. 42 (1996) 3267-3282.

[2] T.K. Poddar, S. Majumdar, K.K. Sirkar, Removal of VOCs from air by membrane-based absorption and stripping, J. Membr. Sci. 120 (1996) 221-237.

[3] T.K. Poddar, K. Sirkar, A hybrid vapor permeation and membrane-based absorption-stripping for VOC removal and recovery from gaseous emissions, J. Membr. Sci. (1997) 229-233.

[4] V.M. Vorotynsev, P.N. Drozdov, E.Y. Kolotov, Gas mixtures separation by an absorbing pervaporation method, Desalination 149 (2002) 23-27.

[5] F. Heymes, P. Manno Demoustier, F. Charbit, J.L. Fanlo, M.P. A new efficient absorption liquid to treat exhaust air loaded with toluene, Chem. Eng. Sci., 115 (2006) 225-231.

[6] W. Weisweiler, H. Winterbauer, Alternatives Auswahlkriterium für Waschflüssigkeiten zur Absorption flüchtiger organischer Verbindungen, Staub-Rheinhaltung der Luft 55 (1995) 221-228.

[7] J.J. Carrol, What is Henry's law? Chem. Eng. Prog. 87 (1991) 45-52.

[8] P. Moulin, T. Allouane, L. Latapie, C. Raufast, F. Charbit, Treatment and valorisation of an industrial effluent by pervaporation, J. Membr. Sci. 197 (2002) 103-115.

[9] P. Sampranpiboon, R. Jiraratananon, D. Uttapap, X. Feng, R.Y.M. Huang, Separation of aroma compounds from aqueous solutions 
+ Model

MEMSCI 7401 1-10

10

F. Heymes et al. / Journal of Membrane Science xxx (2006) xxx-xxx

585

586

587

588

589

590

591

592

593

594

595

596

597

598

599

600

601

602

603

604

605

606

607 by pervaporation using polyoctylmethyl siloxane (POMS) and polydimethyl siloxane (PDMS) membranes, J. Membr. Sci. 174 (2000) 5565.

[10] B. Smitha, D. Suhanya, S. Sridhar, M. Ramakrishna, Separation of organic-organic mixtures by pervaporation-a review, J. Membr. Sci. 241 (2004) 1-21.

[11] V.S. Cunha, M.L.L. Paredes, C.P. Borges, A.C. Habert, R. Nobrega, Removal of aromatics from multicomponent organic mixtures by pervaporation using polyurethane membranes: experimental and modelling, J. Membr. Sci. (2002) 277-290.

[12] Q.F. An, J.W. Qian, H.B. Sun, L.N. Wang, L. Zhang, H.L. Chen, Compatibility of PVC/EVA blends and the pervaporation of their blend membranes for benzene/cyclohexane mixtures, J. Membr. Sci. 222 (2003) $113-122$.

[13] H. Wang, K. Tanaka, H. Kita, K.-i. Okamoto, Pervaporation of aromatic/non-aromatic hydrocarbon mixtures through plasma-grafted membranes, J. Membr. Sci. 154 (1999) 221-228.

[14] J. Frahn, G. Malsch, H. Matuschewski, U. Schedler, H.-H. Schwarz, Separation of aromatic/aliphatic hydrocarbons by photo-modified poly(acrylonitrile) membranes, J. Membr. Sci. 234 (2004) 5565.

[15] S. Matsui, D.R. Paul, Pervaporation separation of aromatic/aliphatic hydrocarbons by a series of ionically crosslinked poly(n-alkyl acrylate) membranes, J. Membr. Sci. 213 (2003) 67-83.
[16] D. Roizard, A. Nilly, P. Lochon, Preparation and study of crosslinked polyurethane films to fractionate toluène-n-heptane mixtures by pervaporation, Sep. Purif. Technol. 23-23 (2001) 45-52.

[17] H.L. Chen, L.G. Wu, J. Tan, C.L. Zhu, PVA membrane filled and betacyclodextrin for separation of isomeric xylènes by pervaporation, Chem. Ing. J. (2000) 159-164.

[18] I. De Bo, H. Van Langenhove, J. De Keisjser, Application of vapour phase calibration method for determination of sorption of gases and VOC in polydimethylsiloxane membranes, J. Membr. Sci. 209 (2002) $39-52$.

[19] P. Hickey, C.H. Gooding, Mass transfer in spiral wound pervaporation modules, J. Membr. Sci. 92 (1994) 59.

[20] E. Boscaini, M.A. Alexander, P. Prazeller, T.D. Märk, Investigation of fundamental physical properties of a polydimethylsiloxane (PDMS) membrane using a proton transfer reaction mass spectrometer (PTRMS), Int. J. Mass Spectr. 239 (2004) 179-186.

[21] F.T. De Bruijn, L. Sun, Z. Olujic, P.J. Jansens, F. Kapteijn, Influence of the support layer on the flux limitation in pervaporation, J. Membr. Sci. 223 (2003) 141-156.

[22] E. Favre, Temperature polarization in pervaporation, Desalination $154_{\bar{\lambda}}$ 129-138.

[23] M. Leeman, G. Eigenberger, H. Strathmann, Vapour permetation for the recovery or organic solvents from waste air streams: separation capacities and process optimisation, J. Membr. Sci. 113 (1996) 313.
608

609

610

611

612

613

614

615

616

617

618

619

620

621

622

623

624

625

626

627

628

629

630

631

Please cite this article as: F. Heymes et al., Recovery of toluene from high temperature boiling absorbents by pervaporation, Journal of Membrane Science (2006), doi:10.1016/j.memsci.2006.07.029. 